\title{
The Impact of Obstacle to Civil Liberties on Declining Democracy Index in West Sumatra: Critical Discourse Comparison Study
}

\author{
Agustina $^{1}$, Muhammad Adek ${ }^{2}$ \\ \{tien agustina08@yahoo.com ${ }^{1}, \underline{\text { marximalize@ } @ \text { fbs.unp.ac.id }}^{2}$ \} \\ ${ }^{1,2}$ Universitas Negeri Padang, Indonesia
}

\begin{abstract}
The Central Statistics Agency (BPS) reported that Democracy Index of West Sumatra province has decreased significantly in 2016. This fact is quite an anomaly if it refers to the Minangkabau indigenous roots and philosophical foundations which is claimed to be compatible with universal democratic principles. The latest regional autonomy policy made the West Sumatra regional government be allowed to implement local policies which for decades was repressed by the central government. The gap in vision between the West Sumatra Provincial Government and the Central Government is widening with evidence number of cancellations proposed local regulation (Perda). Disputes between regional and central democratic discourse are recorded in the text of the mass media as research data Afterward, this study aimed to conduct a comparative and critical discourse analysis by comparing between the central and regional discourse regarding the implementation of democratic activities. The 'civil liberties' aspect was decided as the focus of the problem and became a benchmark for democratic practices in this discussion. The result of data analysis indicates that the configuration of local and central government discourse regarding the enforcement and protection of civil liberties differs in application, ideas and goals. Thus, this antagonism widens the gap between democratic practices and ideals between regional and central governments.
\end{abstract}

Keywords: discourse analysis, democracy index, civil liberties

\section{Introduction}

Based on reports ${ }^{[1]}$ compiled by the Central Statistics Agency (BPS) for the 2016 calculation year, the Indonesian Democracy Index (IDI) nationally decreased by 2.74 compared to the estimation in the previous year. However, if calculated as a whole, the condition of democracy in Indonesia has a tendency to "increase" since it was first calculated in 2009. In this 2016 calculation year, bad grades were received by West Sumatra province as the lowest rank, and the only province with a democratic assessment categorized as "poor" among the other provinces. As a province with a majority population known for its egalitarian and moderate ideology, this phenomenon is a bit of an anomaly and quite problematic, especially for local governments in West Sumatra.

Somewhat odd if it refers to West Sumatra's history and development, Minangkabau people have traditional philosophical roots and can be categorized as compatible with democratic terms. Some scholars have researched it and indicated agreement with the above opinion. Abdullah $^{[2]}$ in his paper stated that conflict in finding a solution or decision in Minangkabau is a common even "institutionalized in Adat (tradition)." This is in line with the recommendations of the Pancasila (five pillars) in the fourth precept which demands a debate as a method of 
finding decisions together. Therefore, the equality of the roots of this thought and method should make the democratic process in Minangkabau become 'smoother' ${ }^{[3]}$.

However, since the 1958 incident, the legitimacy and influence of Adat (tradition) in the midst of Minangkabau society as a grip of life began to fade. Tsuyoshi ${ }^{[4]}$ argues that "the combination of internal and external factors, especially interventions from the colonial and postcolonial governments, has increasingly eliminated the position of Adat and Nagari autonomy." This is in line with the results of studies presented by several anthropologists such as Maretin ${ }^{[5]}$ and Swift ${ }^{[6]}$.

After the collapse of the New Order and the development of the Reformation, Adat and local-patterned wisdom in West Sumatra revived. The central government began to issue a policy that encouraged the independence of local governments in managing and developing their own districts. The West Sumatra provincial government can finally re-organize to the government system and its policies in line with local customs. One policy that was applied in West Sumatra was to replace the village term into a nagari $^{[7]}$.

Equitable distribution of power that was previously dominated by the central government to regional governments turned out to create a dilemma. Especially since the launching of West Sumatra Regional Regulation 2003 or largely known as "Perda Kembali ke Nagari", the power of the local government is even greater and increasingly separated from the flow of central policies ${ }^{[8]}$. Local governments have considerable authority in running the government and enforcing local-style regulations. This situation has the potential to deviate from central government policies ${ }^{[9]}$

In connection with assessing the conditions of democracy, local governments are fully responsible for the ups and downs of the democratic index in their respective provinces. One of the indicators that can reduce the quality of democracy is the obstacle to civil liberties ${ }^{[10]}$. The ability of local governments to protect, uphold and fulfill civil rights is one of the important indicators in the good or bad implementation of democracy in a region.

Civil liberties are still very unfamiliar to Indonesian people ${ }^{[11]}$. Since the days of the kingdom, colonialism, the Old Order and the New Order, civil liberties are not an important principle that is understood, respected, even upheld by the leaders. Kings, colonizers and presidents who acted as rulers in Indonesia tend to ignore civil liberties in an effort to seize and maintain power ${ }^{[12]}$. Only after the Reformation era, Indonesia began to make laws specifically to protect, uphold and fulfill human rights, namely Law no. 39 year 1999 which was strengthened by the ratification of the International Covenant on Civil and Political Rights in Law no. 12 year 2005 .

The civil rights enshrined in the Human Rights Protection Act and the International Covenant on Civil and Political Rights ${ }^{[13]}$ include: 1 . Right to life; 2 . Right to be free from torture and inhuman treatment; 3 . Right to be free from slavery and forced labor; 4. Right to personal freedom and security; 5. Right to move and migrate; 6 . Right to recognition and equal treatment before the law; 7. Right to freedom of thought, belief and religion; 8. Right to freedom of opinion and expression; 9. Right to assemble and associate.

Because of its important position in assesing democratic conditions of a government, civil liberties was made as the focus of this study. It means, this article seeks to show the discourse of upholding and protecting human rights related to civil liberties by the regional government as a valid indicator of democratic conditions in West Sumatra. By using the theory of critical discourse analysis, it is hoped that a portrait of democracy implementation related to civil rights can be displayed as one of the human rights guaranteed by the Indonesia goverment. 


\section{Method}

The primary data source in this research was the news script of printed newspaper. The newspaper which is considered representative for this research was Singgalang. This was based on the perception of equality with the methodology of data collection conducted by BPS. Secondary data sources were academic study texts, linguistic theory books, and Constitutional documents that act as supporting data and comparison.

Data collection uses a documentation techniques followed by observing and codifying the manuscript and text. The data is then reduced by a purposive sampling method with reporting indicators related to violations of civil liberties committed by the government or the public. The data obtained are then analyzed based on the grand theory framework BREAK from Sawirman ${ }^{[14]}$ and supported by other linguistic theories (compare with Adek ${ }^{[15]}$ ).

In brief, Sawirman's BREAK theory attempts to compare several discourses based on the main problem in this study: civil liberties. This comparison was conducted in three levels including: (1) position of discourse, to reveal the position of discourse being compared; (2) discourse configuration, to investigate the form, content, and purpose of the discourse with a linguistic approach; and (3) type of discourse movement, to see how the movement of the two discourses in the problem discussed.

Comparative theory of discourse like this is still relatively new, but has the potential to uncover discourses that occur in a comprehensive case. If in general, linguistic theory and discourse ended after finding 'formula', then the BREAK theory goes on to reveal/dismantle the 'essence' and 'spirit' contained in a discourse. This is the starting point of the BREAK theory as a right and proper grand theory to analyze the data in this study.

\section{Result and Discussion}

\subsection{Position of the Discourse}

The position of the discourse is an analytical work of the critical discourse version of the theory of BREAK which is tasked with making a categorization of the selected discourse. The categorization of discourse is divided into two categories, namely primary discourse as the main study of the discussion and secondary discourse as a comparative study. Through this comparison, it is expected that accurate results can be found because systematic analysis is carried out horizontally.

In this case, the categorization of discourse is based on indicators of research objectives, that is to uncover (how) the practice of democracy in particular relating to freedom of assemble and associate for citizen at the praxis level. Therefore, the aspect used as data reference is the event that occurred about its implementation (freedom of assembly) in the midst of the community. Thus, based on the predetermined indicators, the primary discourse in this discussion is 'repressive actions of government officials', while the secondary (comparative) discourse is the 'law/regulation protecting citizens about the freedom of assembly'. The second position of both discourses can be described as follows. 
Table 1.

Identification of Position of Discourse

\begin{tabular}{ccc}
\hline $\begin{array}{c}\text { Position of the } \\
\text { Discourses }\end{array}$ & Primary & Secondary \\
\hline $\begin{array}{c}\text { Based on the research } \\
\text { focus }\end{array}$ & $\begin{array}{c}\text { Repressive actions } \\
\text { by government } \\
\text { officials/apparatus }\end{array}$ & $\begin{array}{c}\text { Laws / regulations } \\
\text { concerning the protection of } \\
\text { citizens' freedom of assemble } \\
\text { and associate }\end{array}$ \\
\hline
\end{tabular}

\subsection{Configuration of the Discourse}

\section{PRIMARY DISCOURSE}

\section{a. Form Analysis}

The advantages of BREAK discourse analysis include being able to explore deeper all the structural elements of the discourse in the form of research data text ${ }^{[13]}$. To dismantle the formula, linguistic analysis was conducted on all elements related to the structure of the data text from the mass media about the "repressive actions" of the authorities over freedom of assembly for the community.

One of the most important elements of a text revealed in a proposition is predicate function, both typical and categorical. The choice of a typical predicate can determine the presence of a subject and the number of objects needed. Meanwhile, the selection of the predicate category will determine the way the subject treats objects in a sentence.

Based on the typical predicate used in this research data, passive predicate was found to be more dominant than active predicate. Passive predicate types are displayed with different sentence structures. The first structure is in the form of a passive transitive sentence by omitting the subject (doer).

1. Empat wanita mabuk diamankan (Id1, S:3/2/16)

Four drunken women were secured

2. Main game play station 21 pelajar diamankan (Id1, S:4/2/16)

Playing game in playstation, 21 students were secured

3. Dua sejoli digrebek di Bukit Lampu (Id1, S:26/3/16)

A couple was raided in Bukit Lampu

4. Dua pasangan ilegal ditangkap (Id1, S:15/2/16))

Two illegal couples were captured

5. 39 muda-mudi terjaring (Id1, S:27/2/16)

39 teenagers were trapped

In general, the predicate function filled filled with transitive verbs indicates that the SubjectActor's presence is optional (may exist or not). However, in the (title) reporting of all five data, the function of the subject of enforcement as the realization of the event 'secured, raided, captured, trapped' deletion or hidden with purpose to highlight the function of the object as target of the action.

The emphasis of the object is very visible from the choice of verbs as a predicate filler, which textually presents different meanings but with the similar purpose. For example verb 'secured' in (1) and (2) are considered to be more familiar as formal work for the state apparatus in 
handling an incident, and the verbs 'raided' (3) and 'captured' (4) contain very formal situation, and 'trapped' (5) seems to mean accidentally, even though it is conducted in a place with a formal identity (hotel). However, in the context of enforcing democracy, all data connotes exaggerating (pleonasm) the occurred events for the result the targeted object is exposed, to make the intention that the case is very urgent and important to handle.

The use of the pleoname is strengthened by the attributes presented. In data (1), the predicate 'secured' and 'captured' (4) are aimed at highlighting female target objects with quantitative attributes of four (1) and two (4) together with 'drunk' (1) and 'illegal' (4) so that the object being targeted is fully described with its characteristics and identities. Same thing with data (3) the attribute 'lovebirds' for two (couple), in data (4) the 'middle-aged' attribute as a nonrestrictive aposition for a partner, and in data (5) the word 'pervert' as an attribute of a partner. Meanwhile, in the data (2) the target object is preceded by the description 'playing game playstation' as a result of (cause) occurrence 'secured' event of these ' 21 students.'

It can be concluded that the use of the passive-ditransitive predicate with the omission of $\mathrm{S}$ Actor pattern (-S Actors), indicates there is inequality of treatment to the object. This is manifested by putting entirely faults on the object/target so it has implications for so it has implications for negligence or restriction of the right to assembly and associate for some people or groups.

The second structure is passive-ditransitive sentences by the presence of the subject as an actor (+ Actor).

6. 19 Pelajar SMK ditertibkan Satpol PP 7 (Id1,S:15/1/16)

19 SMK Students were disciplined by Satpol PP 7

7. 35 wanita dan 8 pria (ABG) dijaring Satpol PP 13 (Id, S:14/3/16)

35 women and 8 men (ABG) were trapped by Satpol PP 13

8. Lagi 29 pelajar diamankan Satpol PP (Id1,S:18/12/16)

Again, 29 students were secured by Satpol PP

9. Pacaran di jam sekolah, 8 pelajar digaruk Pol PP (Id1, S:5/10/16)

Dating in school hours, 8 students were grabbed by Pol PP

The use of passive predicates with verbs such as '(be) disciplined' (6), 'trapped' (7), 'secured' (8), and 'grabbed' (9) show that more emphasis on the object as the target party through the fronting of the transformative subject of the active structure. However, with the presence of the subject which is textually, pointed out as if the events were happening in a balanced way. This explains the presence of the sweeped party and sweeping party. However, in relation to the enforcement of democracy in Indicator 1 (freedom of assembly), there is an inequality between 'structural power' by Satpol PP as the authorities and 'neglecting freedom of assembly' by students and teenagers as the targeted party, although in a formal level.

The choice of words for verbs used contextually also shows inequality of treatment, although textually verbs 'disciplined' (6) and 'secured' (8) mean non-formal familiar. However, verbs such like 'trapped' (7) and 'grabbed' (8) mean displaying structural power that shows the object becomes the highpoint of the news. Object emphasis also repeats in the Subject's presence pattern, which is equipped with quantitative and attributive adverbials, such as 19 (students) SMK in the data (6), 35 (women) and 8 (men) - (teenangers) in the data (7) and 29 (students) in the data (8).

On the contrary, in data (9), the pattern of causation repeats because of dating in schoolhours resulting in an event ('grabbed') by Pol PP. All of it aims to convince the reader along with affirmation of events conducted by the authorities is a must. It aims to obey general norm 
prevailing in society that what is wrong must be dealt with, even though in perspective of democracy, those mistakes do not harm any people/parties.

The next sentence structure found in this study is active-predicate with monotransitive verb type.

10. Tim gabungan amankan enam pasangan ilegal (Id1, S:2/2/16)

The collective team secured six illegal couples

11. Satpol PP amankan 18 pelajar di warnet (Id1, S:8/12/16)

Satpol PP secured 18 students in internet cafes

12. PP amankan puluhan pelajar (id1, S:17/10/16)

PP secured dozens of students

13. Satpol PP tertibkan 163 pelajar (Id,S:7/10/16)

Satpol PP disciplined 163 students

Monotransitive verbs are transitive verbs that require two arguments as core elements such as subject (actor) and object (target). Although factually, the reference of the perpetrators of the prosecution event in the data (10-13) is different, but generally the subject of the perpetrators was 'Satpol PP'; meanwhile, the target objects are high school/vocational high school students, teenage couples, and drunk women with unmarried status (because those who are married are already in the category of violations of criminal law, not violations of democracy).

The choice of active sentence structure usually aims to highlight the perpetrators of an event. In this research data, the emphasis of the actors in the data to openly display 'structural power' as the party that has to swipe the 'violation' event by utilizing the paradigm that applies in society that the guilty must be disciplined. In the 'must be followed up' situation, object marginalization is occurred in the active structure. The emphasis of the perpetrators also uses the same pattern with the addition of quantitative adverbial and affirmation of object marginalization as a party that must receive repressive action.

\section{b. Essence Analysis}

The essence of discourse features functions to extract messages or meanings stored in the discursive form. Therefore, based on the results of the analysis in the discursive form, there are three conclusions that must be interpreted further in this section. This discussion concerns the structure of the news text that uses (1) passive-ditransitive structure with omission of actors; (2) passive-ditransitive structure the presence of the perpetrator, and (3) the structure of monotransitive-active sentence.

In general, there are two typical sentence structures about realization of freedom of assembly and associate for the citizen in mass media reporting, namely active and passive structures. The choice of the two structures is based on specific goals and purposes. Textually and theoretically, active verbalized sentences are sentences the $\mathrm{S}$ (ubject) acts as the actor (agent) or respondent (experiencer). On the contrary, sentences with the predicate of passive verbs is a sentence whose subject is acting as sufferer, target, or outcome; in this case, the subject of passive sentences is transformation of the Object function in the active sentence.

The structure of active sentences aims to describe events by displaying subjects and objects transparently with the result, the subject's role towards the object being targeted massively displayed in the external structure (surface structure). Therefore, topically, the subject is positioned at the beginning of the sentence with the function of regulating the activities to be played by predicate on objects, so the relationship between subject and object seems to be displayed in a balanced way despite the fact that the highlighting of the subject is prioritized. 
Oppositely, the passive structure aims at describing events focusing on displaying surface subjects (or target objects in a deep structure) but not always (optional) brings up the subject function of the perpetrator in the surface structure. Therefore, topically, the subject is positioned at the beginning of the sentence as a target the subject is positioned at the beginning of the sentence as a target or sufferers due to predicate activity by order played by the subject of the perpetrator, so the relation between subject and object displayed unfairly because of the emphasis of the object as the target recipient which is the main focus while the function of the perpetrator is obscured or hidden.

Based on this concept, the use of passive-ditransitive predicates with the omission pattern of the subject-actors above, represents the authorities as a perpetrator deletion in the outer structure (surface structure) with the aim of 'fully' highlighting mistakes on the target object as a party that must be removed and eliminated. On the other hand, the structure hides or eliminates the subject-actors as the party taking action. Meanwhile, the use of passive-ditransitive predicate with the pattern of presenting the subject of the perpetrator, for the purpose of disguising or obscuring the subject-actor because the main focus of the news and action is the emphasis of the target object. However, it is rather different in data using active-monotransitive sentence patterns, highlighting the subject as the real perpetrator indictes the use of structural power has occured for government officials who are entitled and must take action on the case.

Based on the explanation above, the handling of the case of freedom of association and assemble for citizens was performed by government officials at a practical level with a vertical pattern, which indicates an imbalance of treatment to the object by putting the mistake completely on the target object ${ }^{[14]}$. In fact, the target objects are students/teenagers/teens who are psychologically unstable and need guidance which ultimately have implications of neglecting or a restriction on the right of assembly for the citizen individually and/or in groups.

\section{c. Spirit Analysis}

The transparency of Subject and Object's identity in the discourse of government repressive action shows the spirit of an unapologetic power demonstration ${ }^{[15]}$. This explicit exposure shows a portion of power which is not balanced between citizens and the government and later it is expected to give birth to knowledge in the form of discipline to fear in the community. Through this discourse, mass media texts suggest that subject-actors who are the state apparatus are free in performing duties on orders from their chief. Enforcement of regulations on the object-victim is normalized as a consequence of the unlimited authority of government administrators.

Next, Object fronting-process without presenting the Subject function shows the spirit of blaming entirely on citizens (victim-blaming). With emphasis on talking about the Objectpatients by placing it at the beginning of the proposition, this structure will be oriented to logic of reciprocal action. In another sense, the action received by citizensis derived from their own actions. Obviously, this assumes that, the disciplined or captured citizen is a violator or negligent. With this sequences and logic, the state and its apparatus will always be in an innocent position.

On the other hand, fronting the Object with the presence of the Subject reflects the spirit of the omnipresent country. In more detail, the legal apparatus as an extension of the state will always be present in every form of violation. The state and goverment does not neglect any violations because of this will have an impact on citizen discipline. Although the target of these actions is the citizens. This orientation shows the long history the Indonesian state under the New Order period idolize and glorify country and all kinds of symbols. 


\section{SECONDARY DISCOURSE}

Discourse that acts as a comparison of primary discourse is recognition and protection of the basic rights of citizens or referred to as Human Rights (hereinafter HAM). The formal object comes from Law document no. 39 year 2009 concerning Human Rights.

\section{a. Form Analysis}

In general, the linguistic form of the second discourse of recognition and protection of human rights is a commissive illocutionary act (hereafter CIA). Wijana ${ }^{[16]}$ defines the CIA as a speech that engage the speaker (origin of the word 'commit') with to take the action as promised. So, the emphasis on the burden and action of this speech act rests with the speaker. It means, the speaker is the center of his speech. In relation to the discourse on the recognition and protection of human rights as a secondary discourse, the government and the people of Indonesia are subject to this agreement.

Some of the locus of the CIA listed in the text of the Law on Human Rights related to primary discourse are as follows:

(1) Hak Asasi Manusia adalah seperangkat hak yang melekat pada hakikat dan keberadaan manusia sebagai mahkluk Tuhan Yang Maha Esa dan merupakan anugerah-Nya yang wajib dihormati, dijunjung tinggi dan dilindungi oleh negara, hukum, Pemerintah, dan setiap orang demi kehormatan serta perlindungan harkat dan martabat manusia (pasal 1 ayat 1 ).

Human Rights are a set of rights inherent in the nature and existence of humans as a creature of God Almighty and is a gift that must be respected, upheld and protected by the state, law, government, and everyone for the sake of honor and protection of human dignity (Article 1 paragraph 1).

(2) Negara Republik Indonesia mengakui dan menjunjung tinggi hak asasi manusia dan kebebasan dasar manusia sebagai hak yang secara kodrati melekat pada dan tidak terpisahkan dari manusia, yang harus dilindungi, dihormati, dan ditegakkan demi peningkatan martabat kemanusiaan, kesejahteraan, kebahagiaan, dan kecerdasan serta keadilan (pasal 2).

The Republic of Indonesia recognizes and upholds human rights and basic human freedoms as inherently natural rights and inseparable from humans, which must be protected, respected and upheld for the sake of increasing human dignity, prosperity, happiness, and intelligence and justice (article 2).

(3) Hak untuk hidup, hak untuk tidak disiksa, hak kebebasan pribadi, pikiran dan hati nurani, hak beragama, hak untuk tidak diperbudak, hak untuk diakui sebagai pribadi dan persamaan dihadapan hukum, dan hak untuk tidak dituntut atas dasar hukum yang berlaku surut adalah hak asasi manusia yang tidak dapat dikurangi dalam keadaan apapun dan oleh siapapun (pasal 4).

(4) The right to life, the right not to be tortured, the right to personal freedom, mind and conscience, the right to choose religion, the right not to be enslaved, the right to be recognized as a person and equality before the law, and the right not to be prosecuted on the basis of a retroactive law is a human right that cannot be reduced under any circumstances and by anyone (article 4$)$.

The locutionary presented by article 1 (and paragraph 1) and article 4 is categorized as a commissive locutionary of principle. This means that the speaker promises to recognize the nature of the object of speech specifically the definition of human rights and their derivatives. Locutionary displayed by article 2 has an implementative-commissive type. This utterance 
explain that the speaker promises to implement human rights protection and enforcement as a form of agreement.

\section{b. Essence Analysis}

Based on the analysis of the form, the discourse of protection and enforcement of human rights in Indonesia is seen as the Commisive Illocutionary Act (CIA). The CIA practically has several levels of emphasis, from the weakest to the strongest. This level of engagement power depends on who and what the purpose of the speech. In this context, the discourse on the protection and enforcement of human rights in Indonesia has reached the stage of manifestation and implementation under Indonesian law. The manifestation is in the form of a material law; implementation in the field as an immaterial form. This means the discourse of human rights enforcement is a principle that must be upheld together by the government and the people and maintained in state and democratic life based on applicable law.

Commissive Illocutionary principle conveys the idea that every Indonesian citizen have basic rights that must be recognized and fulfilled. The types of rights include the rights to assemble and associate, political rights, and the right to live properly. Describing the definition of human rights and their derivatives in a long and detailed proposition shows the intention that the understanding and enforcement of human rights are not understood thoroughly by the public. Thus, misappropriation of human rights by several parties such as state apparatus, mass organizations, and community groups are quite common in Indonesia ${ }^{[19]}$. We can refer to several cases of immense human rights violations during the New Order such as the Civil Genocide (1965), Petrus Case (1982-85), Case of Tanjung Priok (1984), Case of May and Semanggi (1998).

The commissive-implementative illocution has a motive that human rights must be upheld and protected by the speaker who is bound by the speech. After becoming a material form, namely the Law, the effort to uphold human rights in Indonesia has received guarantees and a strong foundation. The enactment of upholding and protecting human rights can also be seen as implementing democratic values in the state.

\section{c. Spirit Analysis}

The spirit contained in the discourse of upholding and protecting human rights is reconciliation. The reconciliation refers to the gradual recovery of the protection and enforcement of the human rights. During the thirty-two years of the authoritarian New Order regime, the existence of human rights is almost never recognized as a principle and a right inherent in every citizen ${ }^{[20]}$. The state with unlimited power and supported by military apparatuses can arbitrarily deny even violate human rights without being touched by legal hands ${ }^{[21]}$. Therefore, the State's current and future efforts is to protect and uphold human rights requires awareness, patience and adaptation.

After the Reformation, the Indonesian government wants to put HAM back in its original position. This huge plan certainly cannot work directly and massively. The domination of power of politicians and bureaucrats with New Order background in strategic positions in the government, certainly still and will interrupt human rights repositioning as they should. Reconciliation is expected to be able to restore the position of human rights gradually while promoting human rights in the midst of society.

\subsection{Type of Movement of the Discourses}


Based on the analysis results on discourse configuration features, then the type of movement of the two comparing discourse above can be illustrated through the following table:

Table 2. Comparison of Discourse Movement

\begin{tabular}{ccc}
\hline & Primary Discourse & Secondary Discourse \\
\hline Essence & $\begin{array}{c}\text { Indefference to Human } \\
\text { Rights }\end{array}$ & $\begin{array}{c}\text { Socialization of } \\
\text { Human Rights }\end{array}$ \\
\hline Spirit & Antagonism & Reconcialition \\
\hline Result & Undemocratic & Democratic \\
& atmosphere & atmosphere \\
\hline Type of & Divergen & Divergen \\
movements & (DI) & (DI) \\
\hline
\end{tabular}

Based on the discourse comparison table, then only single type of discourse movement is obtained, namely divergent-divergent (DI-DI). The characteristics of the movements of these two discourses is conflicting and contradictory. It means, the essence and spirit contained in the two discourses have opposing and contrasting goals.

Messages captured from primary and secondary discourse are highly different. That is, the idea of the government to promote human rights still faces obstacles, especially in the regions and districts. Local governments still overlook the principles and values of human rights and tend to act as antagonistic actors when dealing with civil society. The spirit of reconciliation resonated by the central government to pick up the backwardness and downturn of the understanding of human rights during this time still deadlocked.

\section{Conclusion}

This research seeks to explore motives behind the low index of democracy in the province of West Sumatra. Indicators used in this study in accordance with BPS's methodology in in measuring the index of democracy especially freedom of association and assemble. This violation of freedom of association and association traced from the news in the mass media text was chosen as the source of data.

Specifically, this research investigates the position of each discourse, how the configuration of each discourse, and how the pattern of the three discourse movements in describing the implementation of democracy at the regional level. The comparing discourses are discussed through the paradigm that discourse is the practice of power/knowledge in conducting its functions and influences on its citizens.

According to the analysis of the discursive position, the primary discourse is occupied by the repressive actions of the local government; Secondary discourse is the protection and enforcement of human rights by the central government. This classification is based on the focus of research which is the form of implementing democracy focusing on civil liberties. Besides, the main discourse also focuses on the analysis of repressive actions of the state apparatus as an extension of the regional government in restricting freedom of association and assemble.

Discourse configuration implies several important points. Primary discourse contains sentence structure that has been inverted such as passivation or Subject omission. Passivization by fronting Object functions bring the 'victim-blaming' message to citizens and approval of repressive actions by government officials. This is driven by the spirit of antagonism which places citizens as 'targets', not as protected objects. Secondary discourse is in the form of 
commissive speech acts with the essence of socialization of human rights with the aim of reconciliation. Based on the essence and spirit of the two discourse being compared, then the type of discourse movement is divergent-divergent (DI-DI). This means that the two discourses have different visions and oppose each other.

Analysis of the basic features of the two discourses compared in this paper offers at least three important points. First, there is a difference in vision between the central government and the regions, especially in aspects of upholding and protecting human rights. Second, the knowledge and awareness of the apparatus and bureaucrats in the regions, especially in the field of human rights is still relatively low. Third, repressive actions from the West Sumatra provincial government contributed to the decline in the democratic index number at the provincial level.

\section{Acknowledgement}

This research was funded by Ministry of Research, Technology and Higher Education DRPM through DIPA-042.06.1.401516 / 2019. For this reason, the thanks go to the Minister and Director General of DRPM through the Chancellor and Chairperson of LP2M of Universitas Negeri Padang.

\section{REFERENCES}

[1] Badan Pusat Statistik. Indeks Demokrasi Indonesia 2016. Jakarta: Kementrian Koordinator Bidang Politik, Hukum dan Keamanan, 2017, pp. 1.

[2] T. Abdullah. "Adat and Islam: An Examination of Conflict in Minangkabau." Indonesia, vol. 3, 1966, pp. 1-24.

[3] T. Abdullah. "Modernization in the Minangkabau World," in Culture and Politics in Indonesia (Eds.) Calire Holt et al., (Ithaca: Cornell Univ Press), 1972, pp. 183-84.

[4] K. Tsuyoshi, Central Pillars of the House. Sisters, Wives and Mothers in a Rural Community in Minangkabau, West Sumatra. Leiden: Research School CNWS Leiden University, 1998.

[5] J. Maretin, "Disappearance of Matriclan Survivals in Minangkabau Family and Marriage.” Bijdragen tot de Tal-, Land-en Volkenkunde, vol. 117, 2013, pp. 304.

[6] M. G. Swift, "Minangkabau and Modernization.” In H. R. Hiatt and C. J. Jayawardena (Eds), Anthropology in Oceania: Essays Presented to Ian Hogbin, Sydney: Angus and Robertson, 1971, pp. 255-267.

[7] P. R. Sanday, Women at the Center: Life in a Modern Matriarchy. Ithaca, NY: Cornell University Press, 2002.

[8] A. Kahin. Rebellion to Integration: West Sumatra and the Indonesian Policy, 1926-1998. Amsterdam: Amsterdam University Press, 2000.

[9] I, Amal, Regional and central government in Indonesian Politics: West Sumatra and South Sulawesi 1949-1979. Yogyakarta: UGM Press, 1992.

[10] Sukirno, "Diskriminasi Pemenuhan Hak Sipil Bagi Penganut Agama Lokal," Administrative Law \& Governance Journal, vol. 1, no. 3, Dec. 2018, pp. 231-239. https://doi.org/10.14710/alj.v1i3.231 - 239

[11] A. Savirani and O. Tornquist (Eds). Reclaiming the State: Overcoming Problems of Democracy in Post-Suharto Indonesia. Yogyakarta: PolGov and PCD Press, 2015.

[12] J. A. Winters. Oligarchy and Democracy in Indonesia. Indonesia, vol. 96, 2013, pp. 1133. 
[13] W. M. Sullivan and W. Kymlicka, "International Covenant on Civil and Political Rights," in The Globalization of Ethics: Religious and Secular Perspectives, W. M. Sullivan and W. Kymlicka, Eds. Cambridge: Cambridge University Press, 2007, pp. 219-228.

[14] Sawirman. E135 Reader: Media Meliput Teror. Jakarta: Pusat Studi Ketahanan Nasional-Universitas Andalas, 2014.

[15] M. Adek. "Analisis Perbandingan Wacana Kampanye Hitam dan Putih tentang Jokowi pada Pilpres 2014 dan Pergerakan Wacananya". Thesis. Dep. Linguistics. Universitas Andalas, Padang, 2016.

[16] J. Honna, Military Politics and Democratization in Indonesia. London: Routledge, 2013.

[17] A. Heryanto, \& S. K. Mandal, "Challenges to authoritarianism in Indonesia and Malaysia.” In Challenging Authoritarian Rule-SEA NIP. London: Routledge, 2013, pp. 11-33.

[18] I. D. P. Wijana, Pengantar Semantik Bahasa Indonesia. Yogyakarta: Universitas Gadjah Mada Yogyakarta dan Pustaka Belajar, 2015.

[19] M. Zed, "Hidden History: Sejarah Kebrutalan dan Kejahatan Negara Melawan Kemanusiaan. Isu-isu Strategi dalam Konteks Sejarah Indonesia.” Jurnal Demokrasi dan HAM, vol. 2, no. 1, 2002.

[20] B. Anderson, "Exit Suharto.” New Left Review, vol. 50, 2008.

[21] C. Budiardjo, "The Legacy of the Suharto Dictatorship." In The East Timor Question: The Struggle for Independence from Indonesia, 2000. pp. 51-67. 